\title{
BIRDS OF THE WORLD: RECOMMENDED ENGLISH NAMES
}

Gill, F.B. \& Wright, M. 2006. Princeton, NJ, and London, UK: Princeton University Press. 259 pp. with CD containing Microsoft Excel spreadsheets of species lists. Soft cover. ISBN 0691128278. US\$20.

Birds are among the few taxa for which non-scientific vernacular names are extensively used in scientific communication as well as in the burgeoning birding community. Consequently, there is a need to have some consistency in the names used around the world. The International Ornithological Congress (IOC) sought to reach consensus in vernacular names for commonly used languages. Standardized names have been published for French (Devillers and Ouellet 1993) and Spanish (Bernis 1995). The goal of Birds of the World: Recommended English Names is to promote a set of unique English names for the extant bird species of the world. Led originally by the now-late Burt Monroe, and then Frank Gill and Minturn Wright, an IOC committee and regional subcommittees have been wrestling with this issue for 15 years. Gill and Wright acknowledge that reaching complete global consensus on names and spelling is unlikely, and they present this list as a first phase of an ongoing process.

The committee developed principles and rules for deciding on names (e.g. existing usage was the predominant guideline; names deemed offensive would be changed; only one name would be promoted for each species) and took a liberal approach to spelling (British vs. American) and the use of one or two words per name. The bulk of the book (200 pages) is a list of species arranged by order and family, giving the recommended English name, scientific name and codes for the geographic region occupied. An alphabetical index covers both English and scientific names. The CD that accompanies the book contains three spreadsheets (non-passerines, sub-oscines and oscines) giving the same species lists as the book, but with more detailed geographic range information. Using the Sort function and other tools in a spreadsheet, rearranging the lists for dozens of different uses, such as regional, alphabetic or taxonomic lists or the tracking of personal global birding efforts is easy.

So what's in it for seabirds? Most seabirds have widely accepted names, and so there are few surprises overall. The greatest variation is seen between existing British and American names for many northern species. Overall the list leans toward American usage, and so it contains Parasitic Jaeger (not Arctic Skua), Red Phalarope (not Grey), and Mew Gull (not Common), among several others. The greatest service this publication can make to marine ornithology is to drive stakes into the hearts of some truly confusing British names. Thankfully Gavia spp. are loons (not divers) and guillemots are in the genus Cepphus only, leaving the two Uria species as Common and Thick-billed Murres. I hope that the editors of ornithology journals rapidly adopt these terms. But the decisions didn't all favour American terms: Little Auk is favoured over Dovekie, and many of the smaller marine cormorants are named as shags.
In addition to competing English names, the IOC committee had to deal with ongoing taxonomic shuffling too. It isn't clear how they reached consensus here, but some recent splits are recognized (e.g. Nazca Booby, Vega Gull, the various sub-Antarctic shags), and others are not (e.g. the suggested splits of Wandering, Yellow-nosed and other albatrosses). As the editors reiterate, this compilation is a work in progress, and future versions will undoubtedly address the changing taxonomic landscape.

Everyone who peruses these lists will be disappointed to see some old favourites voted out and will find fault with some decisions (I think I hear the rumble of European dissent over their guillemots and divers). Personally, I can't understand why Chionis minor gets the perfectly descriptive name Black-faced Sheathbill whereas C. alba retains the least identifiable of its many English names, Snowy Sheathbill (why not Pink-faced, which has gained common usage?). I'm also disappointed to see Jackass Penguin promoted ahead of the more informative and commonly-used name African Penguin.

Overall though, I think that most of us could live with the names suggested. The committee broke several of its own rules to come up with a completely new name for one species: Angel Tern is the name suggested for Gygis alba in place of two other widely used names, Fairy Tern (correctly assigned to Sterna nereis) and White Tern (deemed too bland for such an endearing seabird). An apt new name for this ethereal tern, I think.

The true test of these names will be their adoption by ornithology and birding journals and magazines. Because Birds of the World: Recommended English Names carries the endorsement of the IOC, one hopes that it will be rapidly adopted as the "official" list of English names. Most ornithologists and birders in all parts of the world will want this inexpensive book on their shelves and the spreadsheet on their hard drives.

\section{REFERENCES}

BERNIS, F. 1995. Diccionario de nombres vernaculos de aves. Madrid: Editorial Gredos. 232 pp.

DEVILLERS, P. \& OUELLET, H. 1993. Noms français des oiseaux $\mathrm{du}$ monde avec les equivalents latins et anglais. Sainte-Foy, QC and Chabaud, France: Éditions MultiMondes. 452 pp.

Alan E. Burger, Department of Biology, University of Victoria, Victoria, British Columbia, V8W 3N5, Canada (aburger@uvic.ca) 